\title{
STUDI KINETIKA REAKSI DARI ENZIM $\alpha$ - AMILASE PADA PROSES PENGHILANGAN KANJI KAIN KAPAS
}

\author{
STUDY OF KINETICS OF THE $\alpha$-AMILASE ENZYME REACTION IN DESIZING \\ PROCESS
}

\author{
Gina Puspitasari, Wulan Safrihatini, Khairul Umam \\ Politeknik STTT Bandung, Jl. Jakarta No.31, Bandung, Indonesia \\ E-mail: wulansafrihatini@yahoo.co.id
}

Tanggal diterima: 9 April 2019, direvisi: 5 Juli 2019, disetujui terbit: 12 Juli 2019

\begin{abstract}
ABSTRAK
Enzim alfa amilase merupakan kelompok enzim yang dapat digunakan dalam proses penghilangan kanji alam (desizing), enzim ini akan bertindak sebagai katalis dalam reaksi hidrolisis pati oleh air. Guna mengendalikan aktivitas enzim dalam proses desizing, maka perlu dipahami kemampuan enzim sebagai katalis untuk menghidrolisis pati dengan pengujian kinetika enzim. Pengujian kinetika enzim akan menghasilkan nilai Vmaks dan Km, Vmaks merupakan laju maksimum dari enzim persatuan menit sedangkan $\mathrm{Km}$ merupakan konstanta Michaelis Menten yang menggambarkan kesetimbangan disosiasi kompleks ES menjadi enzim dan substrat. Pengujian ini dilakukan untuk mengetahui kemampuan enzim $\alpha$-amilase dalam mengkatalisis reaksi hidrolisis pati agar diperoleh efisiensi penggunaan enzim juga waktu pada proses desizing. Pengujian akan menggunakan metode Fisher and Stein (metode DNS). Pengujian dilakukan pada pH 7 dan suhu kamar. Penentuan nilai laju maksimum dan nilai Km dilakukan dengan variasi substrat diukur menggunakan spektrofotometer pada panjang gelombang $540 \mathrm{~nm}$. Nilai $\mathrm{Km}$ dan Vmaks yang diperoleh yaitu 8,874461 dan $0,53217 \mathrm{mg} / \mathrm{menit}$. Data yang diperoleh dari hasil percobaan menunjukkan bahwa makin lama waktu yang digunakan maka makin besar kemampuan enzim tersebut dalam menghidrolisis kanji. Pada waktu 150\% Vmaks, enzim mampu menghidrolisis kanji sebanyak 92,75362\%.
\end{abstract}

Kata kunci: alfa amylase, desizing, enzim, kinetika, pati

\section{ABSTRACT}

Alpha amylase enzyme is a group of enzymes that can be used in the process of removing natural starch (starch), this enzyme will act as a catalyst in the hydrolysis of starch by water. In order to control enzyme activity in the desizing process, it is necessary to understand the ability of the enzyme as a catalyst to hydrolyze starch by testing the enzyme kinetics. Testing of enzyme kinetics will produce Vmax and Km values, Vmax is the maximum rate of enzyme per unit of minutes while Km is the Michaelis Menten constant which describes the dissociation equilibrium of ES complexes into enzymes and substrates. This test is conducted to determine the ability of the $\alpha$ amylase enzyme to catalyze the hydrolysis reaction of starch in order to obtain efficient use of the enzyme as well as the time of the desizing process. The test will use the Fisher and Stein method (DNS method). Tests are carried out at pH 7 and room temperature. Determination of the maximum rate value and Km value is done by substrate variation measured using a spectrophotometer at a wavelength of $540 \mathrm{~nm}$. The Km and Vmax values obtained are 8.874461 and $0.53217 \mathrm{mg} /$ minute. Data obtained from the experimental results show that the longer the time used, the greater the ability of the enzyme to hydrolyze starch. At 150\% Vmax, it isable to hydrolyze starch as much as $92.75362 \%$.

Keywords: alpha amylase, desizing, enzymes, kinetics, starch

\section{PENDAHULUAN}

Proses desizing merupakan proses pretreatment bahan tekstil yang bertujuan untuk menghilangkan kanji dari proses sizing. Lapisan kanji yang masih terdapat pada kain akan menghalangi penyerapan larutan pada proses berikutnya. Kanji yang digunakan untuk serat selulosa biasanya berupa tepung kanji tapioka (pati). Kanji alam merupakan jenis kanji yang memiliki molekul yang sukar larut dalam air yaitu amilopektin sehingga dengan proses penghilangan kanji cara perendaman hanya dapat menghilangkan molekul yang dapat larut dalam air saja yaitu amilosa dalam waktu yang lama. Proses penghilangan kanji alam dapat dilakukan dengan menggunakan enzim amilase, larutan asam, alkali serta oksidasi dengan zat oksidator. ${ }^{7}$ Proses penghilangan kanji (desizing) merupakan proses pretreatment yang bertujuan untuk menghilangkan kanji yang terdapat pada kain hasil pertenunan 
tanpa merusak seratnya. Cara ataupun zat yang digunakan dalam proses penghilangan kanji tergantung pada jenis kanji yang akan dihilangkan. Salah satu jenis kanji yang sering digunakan untuk penganjian benang selulosa adalah kanji alam. Proses penghilangan kanji alam dapat dilakukan dengan menggunakan enzim $\alpha$-amilase dan $\beta$ amilase, larutan asam, alkali serta oksidasi dengan zat oksidator. Metode penghilangan kanji menggunakan enzim merupakan metode penghilangan kanji yang cukup banyak digunakan di industri karena bersifat biodegradable, aman digunakan, tidak merusak serat dan tidak memerlukan suhu yang tinggi.

Enzim $\alpha$-Amilase merupakan enzim yang mampu bertindak sebagai katalis dalam reaksi hidrolisis kanji dalam air membentuk oligosakarida maupun monosakarida berbagai ukuran dengan konfigurasi $\alpha$. Enzim $\alpha$-Amilase memiliki nama kimiawi, yaitu endo-1,4- $\alpha$-D-glucan glucohydrolase. Enzim $\alpha$-Amilase merupakan enzim yang mampu memotong ikatan 1,4- $\alpha-\mathrm{D}$ glikosidik pada bagian dalam rantai amilosa dan amilopektin. Reaksi hidrolisis kanji dapat dilihat pada Gambar 1.

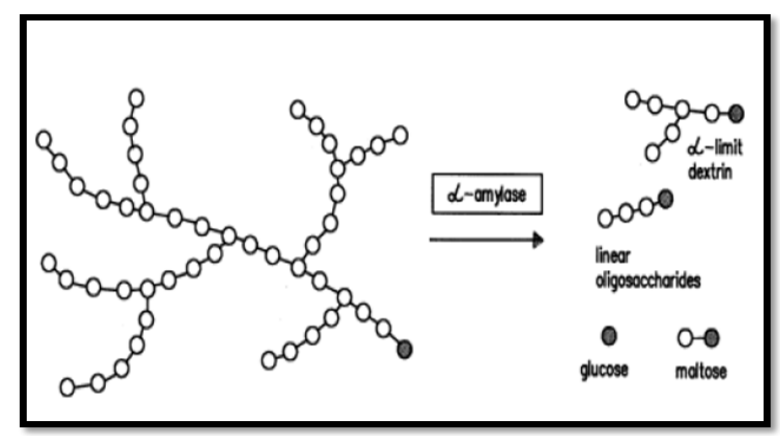

Gambar 1. Hidrolisis kanji oleh enzim $\alpha$-amilase

Amilase ( $\alpha$-amilase, $\beta$-amilase) merupakan kelompok enzim yang dapat digunakan dalam proses penghilangan kanji alam (pati). Enzim amilase mampu bertindak sebagai katalis dalam reaksi hidrolisis pati oleh air. Reaksi enzimatis melibatkan pembentukan kompleks enzim-substrat yang kemudian terurai menjadi produk dan melepaskan enzim kembali. ${ }^{2}$

Parameter dalam kinetika reaksi enzim adalah konstanta Michaelis-Menten (KM). Secara sederhana, hipotesis Michaelis-Menten dapat dituliskan sebagai berikut:

$$
\mathrm{E}+\mathrm{S} \underset{k_{r}}{\stackrel{k_{f}}{\rightleftharpoons}} \mathrm{ES} \stackrel{k_{\text {cat }}}{\longrightarrow} \mathrm{E}+\mathrm{P}
$$

Di mana :

$\mathrm{E}$ : enzim bebas

$\mathrm{S}$ : substrat

ES : kompleks enzim substrat

$\mathrm{P}$ : produk/hasil reaksi

kf : tetapan kesetimbangan reaksi pembentukan ES $\mathrm{kr}$ : tetapan kesetimbangan reaksi penguraian ES kcat : tetapan kesetimbangan reaksi katalitik

Konsentrasi substrat mempengaruhi kecepatan reaksi yang dikatalisis oleh enzim. Pada konsentrasi substrat yang amat rendah, kecepatan reaksipun amat rendah, tetapi kecepatan ini akan meningkat dengan meningkatnya konsentrasi substrat. Pada batas kecepatan maksimum (Vmaks), enzim menjadi jenuh oleh substratnya, dan tidak dapat berfungsi lebih cepat ${ }^{1}$. Guna mengendalikan aktivitas enzim dalam proses desizing, maka perlu dipahami kemampuan enzim sebagai katalis untuk menghidrolisis pati dengan pengujian kinetika enzim.

Percobaan kinetika enzim $\alpha$-Amilase pada dasarnya dapat dilakukan melalui tiga observasi utama, yaitu peningkatan kekuatan reduksi, penurunan intensitas warna biru, dan perubahan densitas optis. Peningkatan kekuatan reduksi diamati dengan pengukuran produk berupa gula pereduksi dari substrat kanji (pati). Penurunan intensitas warna biru senyawa kompleks iodin-kanji terjadi akibat jumlah substrat yang semakin berkurang akibat kinerja enzim untuk menghidrolisis kanji. Perubahan densitas optis terjadi akibat lepasnya substrat dari gugus kromogenik menuju pelarut. ${ }^{9}$

Metode yang dilakukan dalam penelitian ini adalah peningkatan kekuatan reduksi menggunakan reagen DNS. Hidrolisis kanji dalam air dengan bantuan enzim $\alpha$-Amilase menghasilkan molekul oligosakarida dan monosakarida yang mempunyai ujung gugus pereduksi. Ujung gugus pereduksi tersebut mampu mereduksi asam dinitrosalisilat yang berwarna kuning menjadi spesi pereduksinya berwarna jingga. Perubahan tersebut dapat ditentukan dengan analisis spektrofotometri.

Metoda analisis ini dapat menentukan nilai laju maksimum enzim (Vmaks) dan nilai Konstanta Michaelis Menten (Km) yang bekerja dalam menghidrolisis kanji. Nilai laju maksimum (Vmaks) menunjukkan jumlah substrat kanji yang dapat dihidrolisis dalam satuan waktu, sedangkan nilai kontanta Michaelis Menten dapat menunjukkan afinitas enzim terhadap substrat, sehingga dapat diketahui seberapa kuatnya pengikatan substrat kanji pada enzim. ${ }^{3}$

Pengujian menggunakan metode Fisher and Stein (metode DNS) dengan prinsip reduksioksidasi untuk mengetahui $\mathrm{Km}$ dan Vmax dari enzim amilase yang diteliti. Pengujian ini akan dibatasi hanya dengan menggunakan $\mathrm{pH}$ netral yaitu pH 7 dan suhu kamar dengan tujuan agar industri mengetahui kinerja enzim pada kondisi tersebut. Pada kondisi pH 7 dan suhu kamar, artinya dalam proses desizing tersebut tidak memerlukan banyak zat tambahan dan meminimalkan energi 
yang dipergunakan. Kinerja enzim akan lebih baik pada kondisi optimum enzim.

Hasil penelitian nantinya diharapkan dapat digunakan sebagai acuan untuk mengetahui kemampuan enzim $\alpha$-amilase produk dalam menghidrolisis kanji alam pada proses desizing.

\section{METODE}

\section{Bahan}

Bahan yang digunakan dalam percobaan ini adalah kain tenun kapas. Bahan kimia berupa Enzim $\alpha$ - Amilase, $\mathrm{HCl} 1 \mathrm{~N}$, Amilum, Buffer Fosfat, Reagen DNS, $\mathrm{NaCl}$.

\section{Percobaan Kinetika Enzim $\alpha$ - Amilase ${ }^{1}$}

Enzim $\alpha$ - Amilase (aquazym 2401): 0,25 mL/L

Buffer Fosfat $\quad: 0,25 \mathrm{~mL} / \mathrm{L}$

$\mathrm{NaCl} \quad: 0,25 \mathrm{~mL} / \mathrm{L}$

Air Suling $\quad: \mathrm{x} \mathrm{ml} / \mathrm{L}$

Kanji $2 \% \quad: 0,2 ; 0,3 ; 0,4 ; 0,5 ; 0,6 \mathrm{~mL} / \mathrm{L}$

Reagen DNS : $1 \mathrm{~mL} / \mathrm{L}$

Waktu $\quad: 0 ; 10$ menit

Suhu : Suhu kamar

Panjang Gelombang spektrofotometer : $540 \mathrm{~nm}$

\begin{tabular}{|c|c|c|}
\hline \multirow{2}{*}{\multicolumn{3}{|c|}{$\begin{array}{l}\text { Percobaan Proses Desizing } \\
\text { Variasi Waktu Vmaks }\end{array}$}} \\
\hline & & \\
\hline \multicolumn{3}{|c|}{ Enzim $\alpha$ - Amilase (aquazym 2401): 0,25 mL/L } \\
\hline Buffer Fosfat & $: 3 \mathrm{~mL} / \mathrm{L}$ & \\
\hline $\mathrm{NaCl}$ & $: 3 \mathrm{~mL} / \mathrm{L}$ & \\
\hline Air Suling & $: \mathrm{x} \mathrm{ml} / \mathrm{L}$ & \\
\hline Iodin & : $0,25 \mathrm{~mL} / \mathrm{L}$ & \\
\hline Suhu & : Suhu kamar & \\
\hline Waktu & : $50 \% ; 100 \% ; 15$ & $0 \%$ Vmaks \\
\hline
\end{tabular}

\section{Peralatan}

Alat yang digunakan dalam penelitian ini antara lain spektrofotometer UV-Vis, mesin stenter, timbangan digital, gelas piala $250 \mathrm{ml}$, gelas ukur $100 \mathrm{ml}$, pipet tetes, pipet volume $10 \mathrm{ml}$, pipet volume $1 \mathrm{ml}$, labu ukur $100 \mathrm{ml}$, labu ukur $25 \mathrm{ml}$, pengaduk.

\section{HASIL DAN PEMBAHASAN}

Pengujian pengaruh substrat yang terus meningkat untuk memperoleh nilai Vmaks suatu kerja enzim, diketahui dengan menggunakan persamaan Michaelis Menten yang disempurnakan dengan melakukan transformasi persamaan Michaelis Menten yang dinamakan persamaan Lineaweaver Burk. Cara ini dilakukan untuk mengetahui laju maksimum enzim $\alpha$-Amilase dalam menghidrolisis kanji yang nantinya akan dibandingkan dengan laju enzim pada proses desizing pada kain.

Percobaan dilakukan pada dua waktu reaksi yang berbeda yaitu $\mathrm{t}=0$ dan $\mathrm{t}=10$. Pada waktu $\mathrm{t}=10$ dimaksudkan agar enzim dapat bereaksi dengan kanji dalam waktu 10 menit sedangkan pada waktu $\mathrm{t}=0$ menit dimaksudkan sebagai larutan pengontrol terhadap waktu $\mathrm{t}=10$ menit. Percobaan ini dilakukan untuk mengetahui banyaknya kanji yang dapat dikonversi oleh enzim per satuan waktu. Kanji memiliki ujung gugus reduksi dari rantai amilosa dalam jumlah sedikit sehingga dapat dideteksi oleh reagen DNS karena ujung gugus pereduksi tersebut mampu mereduksi asam dinitrosalisilat yang berwarna kuning menjadi spesi pereduksinya berwarna jingga, ${ }^{7}$ maka dengan mengurangi ujung gugus reduksi yang terukur pada $\mathrm{t}=10$ dengan ujung gugus pereduksi yang terukur pada $\mathrm{t}=0$ akan didapatkan hasil dari jumlah ujung gugus pereduksi yang dideteksi reagen DNS yang hanya merupakan hasil kerja dari enzim dalam waktu 10 menit. Percobaan ini dilakukan dengan menggunakan variasi konsentrasi substrat, yaitu pada konsentrasi substrat $10 \mathrm{mg}, 20 \mathrm{mg}, 30 \mathrm{mg}, 40 \mathrm{mg}, 50 \mathrm{mg}, 60$ $\mathrm{mg}$ dan $70 \mathrm{mg}$.

Hasil percobaan menunjukkan bahwa semakin banyak substrat, semakin banyak pula kanji yang dihidrolisis oleh enzim sebagaimana ditunjukkan pada Gambar 2.

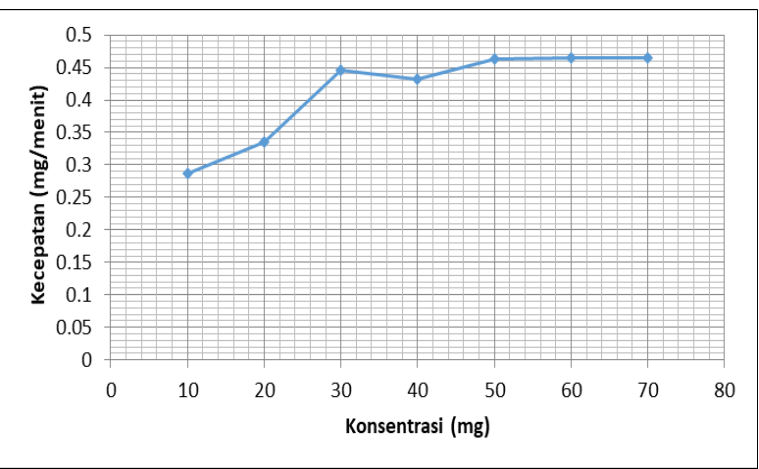

Gambar 2. Grafik pengaruh variasi konsentrasi substrat terhadap kecepatan hidrolisis substrat

Pada Gambar 2 ditunjukkan bahwa, absorbansi semakin meningkat dengan bertambahnya substrat, tetapi mulai titik tertentu (konsentrasi substrat $50 \mathrm{mg}$ ) absorbansi hanya akan meningkat sedikit demi sedikit. Hal ini dikarenakan semua enzim yang terdapat dalam larutan telah dalam keadaan ES atau telah terjenuhi oleh substrat. Persamaan Michaelis Menten yang ditransformasikan dengan cara pemetaan kebalikan ganda menghasilkan suatu persamaan yang dinamakan persamaan Lineaweaver Burk (menjadi plot $[1 / \mathrm{V}]$ terhadap $[1 / \mathrm{S}])$. Grafik Lineaweaver dapat dilihat pada Gambar 3.

Persamaan garis linier Lineaweaver Burk (y $=\mathrm{bx}+\mathrm{a})$ dari penelitian ini adalah $\mathrm{y}=16,676 \mathrm{x}+$ 1,8791, dari pengalihan persamaan Michaelis Menten $(1 / \mathrm{V}=[(\mathrm{Km} / \mathrm{Vmaks})(1 / \mathrm{S})+1 / \mathrm{Vmaks})$. Persamaan tersebut menunjukkan bahwa nilai $\mathrm{a}=$ $1 /$ Vmaks dan nilai $\mathrm{b}=\mathrm{Km} / \mathrm{Vmaks}$, didapat nilai 
Vmaks sebesar $0,53217 \mathrm{mg} /$ menit dan nilai $\mathrm{Km}$ 8,874461 .

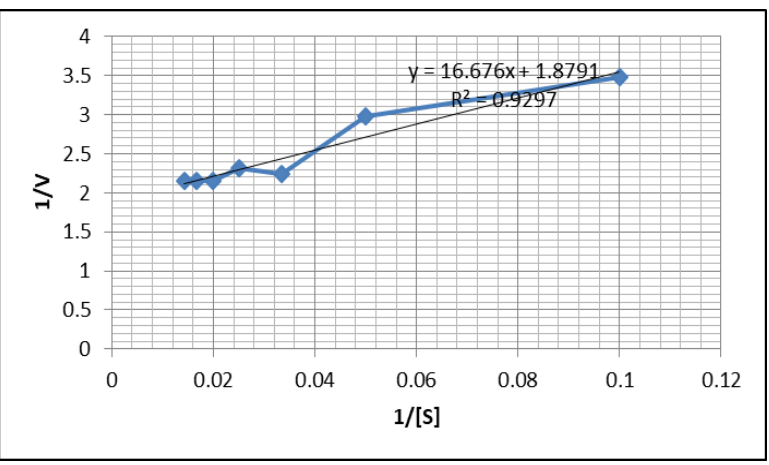

Gambar 3. Grafik Lineaweaver Burk

Vmaks atau laju maksimum dari reaksi enzimatis ini diperoleh dengan nilai 0,5327 $\mathrm{mg} / \mathrm{menit}$. Data tersebut menunjukkan bahwa pada kondisi $\mathrm{pH} 7$ dan suhu kamar, enzim $\alpha$-Amilase sebanyak $0,25 \mathrm{~mL}$ dari hasil pengenceran sebanyak 100.000 kali konsentrat enzim aquazym 2401 dapat mengubah substrat kanji menjadi produk sebesar 0,5327 mg kanji tiap menitnya. Laju enzim dapat naik jika konsentrasi enzim naik. Nilai $\mathrm{Km}$ merupakan konsentrasi substrat yang diperlukan oleh suatu enzim untuk mencapai setengah kelajuan maksimumnya. Setiap enzim memiliki nilai $\mathrm{Km}$ yang berbeda-beda, dan ini dapat menunjukkan seberapa kuatnya ikatan antara enzim dan substrat. Nilai Km menggambarkan kesetimbangan disosiasi kompleks ES menjadi enzim dan substrat. Nilai Km enzim $\alpha$-Amilase yang diuji cukup besar artinya enzim mempunyai afinitas yang rendah terhadap substrat kanji, sehingga kesetimbangan reaksi tidak terjadi ke arah kompleks ES tetapi ke arah reaksi E $+\mathrm{S}$ (konsentrasi substrat tertentu pada saat enzim mencapai $1 / 2$ kecepatan maksimumnya). Nilai $\mathrm{Km}$ enzim $\alpha$-Amilase (aquazym 2401) adalah 8,874461 menandakan bahwa ikatan antara enzim dan substrat cukup rendah.

Hasil dari $\mathrm{Km}$ dan Vmax yang didapat dilanjutkan dengan menganalogikannya pada proses desizing dengan suhu kamar dan $\mathrm{pH}$ 7. Hasil percobaan tersebut dapat dilihat pada Tabel 1 . Waktu percobaan untuk proses desizing ini sebanyak 50\% ( $\approx 19$ menit), $100 \%$ ( $\approx 36$ menit 40 detik), dan $150 \%(\approx 77$ menit 50 detik) dari Vmaks yang didapat. Hal ini dimaksudkan untuk mengetahui efektivitas Vmaks dalam proses desizing. Hasil percobaan dapat dilihat pada Gambar 4.
Tabel 1. Penentuan waktu desizing dengan berdasarkan nilai Vmaks

\begin{tabular}{|c|c|c|c|c|c|c|}
\hline & $\begin{array}{c}\text { Berat } \\
\text { Awal } \\
(\mathrm{g})\end{array}$ & $\begin{array}{c}\text { Berat } \\
\text { Akhir } \\
(\mathrm{g})\end{array}$ & $\begin{array}{c}\text { Kanji } \\
\text { dalam } \\
\text { Kain } \\
(\mathrm{g})\end{array}$ & $\begin{array}{c}\text { Kanji } \\
\text { dalam } \\
\text { Kain } \\
(\mathrm{mg})\end{array}$ & $\begin{array}{c}\text { Waktu Ideal } \\
\text { Berdasarkan } \\
\text { Vmaks }\end{array}$ & $\begin{array}{c}\text { Waktu } \\
\text { yang } \\
\text { digunakan }\end{array}$ \\
\hline Blanko & 1,9175 & 1,9401 & 0,0226 & 22,6 & & 60 menit \\
\hline $\begin{array}{c}1 \\
(50 \% \text { Vmaks })\end{array}$ & 1,7014 & 1,7216 & 0,0202 & 20,2 & $\begin{array}{c}37 \text { menit } \\
58 \text { detik }\end{array}$ & 19 menit \\
\hline 2 & 1,8681 & 1,8876 & 0,0195 & 19,5 & $\begin{array}{c}36 \text { menit } \\
40 \text { detik }\end{array}$ & $\begin{array}{c}36 \text { menit } \\
40 \text { detik }\end{array}$ \\
\hline $\begin{array}{c}(100 \% \text { Vmaks }) \\
(150 \% \text { Vmaks })\end{array}$ & 1,865 & 1,8926 & 0,0276 & 27,6 & $\begin{array}{c}51 \text { menit } \\
53 \text { detik }\end{array}$ & $\begin{array}{c}77 \text { menit } \\
50 \text { detik }\end{array}$ \\
\hline
\end{tabular}

Keterangan: Blanko $=$ desizing tanpa enzim

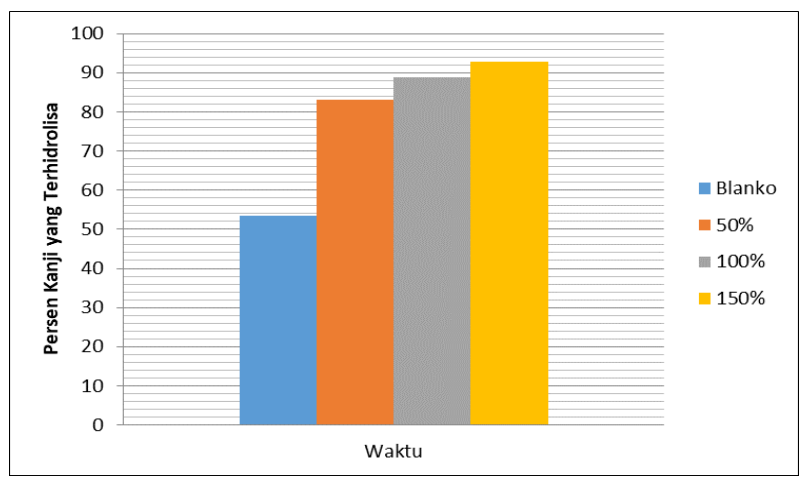

Gambar 4. Persen kanji yang terhidrolisis dengan waktu Vmaks

Gambar 4 menunjukkan bahwa kain blanko (kain yang diproses desizing hanya dengan air) kehilangan kanji sebanyak 53,53\%. Hal ini dikarenakan adanya amilopektin yang merupakan salah satu molekul penyusun kanji yang dapat larut dalam air, sehingga terjadi hidrolisis kanji dalam air tetapi tidak sepenuhnya karena tidak semua molekul yang ada dalam kanji dapat larut dalam air.

Pembuktian selanjutnya untuk mengetahui apakah enzim tersebut dapat menghidrolisis kanji menjadi produk dan dibutuhkannya waktu penetrasi adalah dengan meneteskan iodin ke dalam larutan desizing setelah proses, didapatkan warna yang dapat dilihat pada Gambar 5.

Pada penelitian ini waktu berturut-turut $50 \%$ $(\approx 19$ menit), $100 \%(\approx 36$ menit 40 detik $)$, dan $150 \%$ ( $\approx 77$ menit 50 detik) dari waktu Vmaks dapat menghilangkan kanji sebanyak 83,16832\%, $88,71795 \%$ dan $92,75362 \%$. Dilihat dari hasil tersebut dapat diketahui bahwa penggunaan enzim selama waktu tersebut tidak mampu menghilangkan kanji seluruhnya, kemungkinan hal ini terjadi karena diperlukan waktu penetrasi terlebih dahulu enzim ke dalam serat sebelum akhirnya menghidrolisis kanji. 


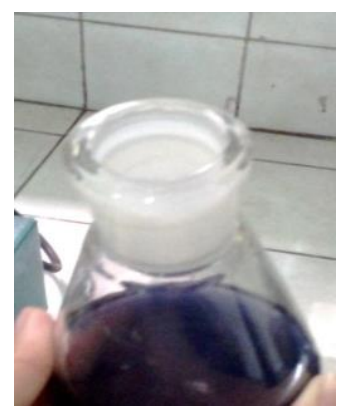

a) Blanko

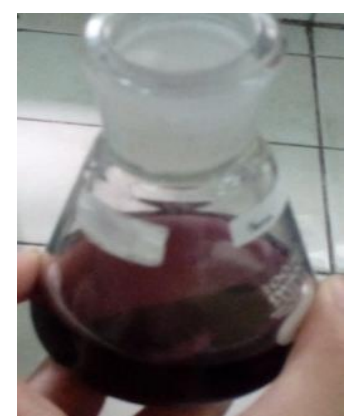

c) Waktu $100 \%$ Vmaks

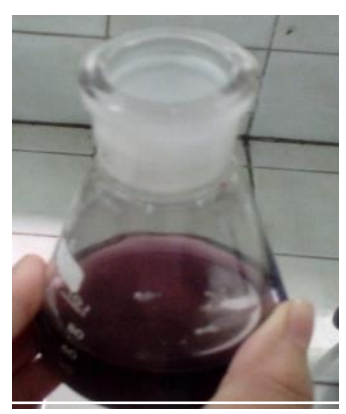

b) Waktu $50 \%$ Vmaks

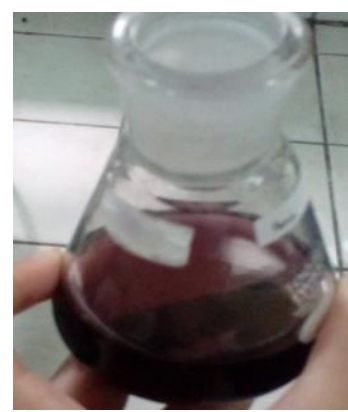

d) Waktu $150 \%$ Vmaks
Gambar 5. Larutan desizing dengan variasi waktu Vmaks setelah ditetesi iodin

Dilihat dari Gambar 5 menunjukkan bahwa proses desizing dengan menggunakan air saja (blanko), larutan penghilangan kanji masih mengandung kanji dan belum menjadi produk sehingga masih membentuk kompleks dengan $\mathrm{KI}_{3}$ menghasilkan warna biru. Kanji akan merefleksikan warna biru bila berupa polimer glukosa yang lebih besar dari dua puluh misalnya molekul- molekul amilosa, ${ }^{5}$ artinya kanji yang terlarut dalam larutan blanko masih berupa molekul amilosa.

Pada penelitian variasi waktu $50 \%, 100 \%$ dan $150 \%$ terlihat bahwa warna larutan desizing saat ditetesi iodin tidak berwarna biru, tetapi memiliki warna violet sampai coklat. Aktivitas $\alpha$ Amilase dapat ditentukan dengan mengukur hasil degradasi kanji (pati), biasanya dari penurunan kadar kanji yang larut atau dari kadar amilosa yang bereaksi dengan iodin ${ }^{10}$ yang artinya dalam larutan tersebut sebagian besar kanji yang larut telah terhidrolisis oleh air dengan bantuan enzim khususnya molekul amilosa karena dilihat dari warna yang terbentuk sudah tidak terbentuk warna biru lagi. Molekul amilosa lebih mudah terhidrolisis karena memiliki rantai yang linier. Bila polimernya kurang dari dua puluh seperti amilopektin maka akan dihasilkan warna merah, sedangkan dekstrin dengan polimer 6,7 dan 8 membentuk warna coklat. ${ }^{6}$ Warna yang dihasilkan dari penambahan iodin ke larutan desizing variasi waktu Vmaks adalah warna violet sampai coklat, mengindikasikan bahwa enzim telah mengkatalisis reaksi hidrolisis kanji dari bentuk polisakarida ke bentuk oligosakarida yaitu eritrodekstrin dan bentuk monosakarida berupa glukosa dan maltosa. Produk berupa monosakarida tidak membentuk kompleks warna dengan iodin sehingga hanya dapat dilihat dengan penurunan intensitas warnanya. Penelitian dilanjutkan dengan mengukur larutan desizing menggunakan spektrofometer untuk mengetahui penurunan intensitas warna larutan desizing variasi waktu Vmaks.

Data kanji yang terhidrolisis menunjukkan bahwa masih ada kanji yang tersisa dalam kain meski telah digunakan 100\% ( $\approx 36$ menit 40 detik $)$ bahkan $150 \%$ ( $\approx 77$ menit 50 detik) waktu Vmaks. Hal ini terjadi kemungkinan karena dibutuhkan waktu penetrasi enzim ke dalam serat terlebih dahulu. Dilihat dari hal ini artinya dalam proses perlu diketahui waktu penetrasi enzim ke dalam serat sebelum akhirnya kinetika enzim diaplikasikan.

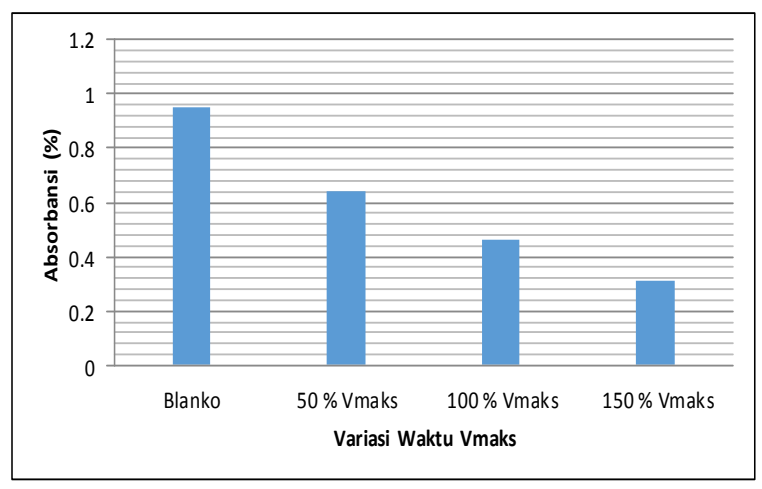

Keterangan :

$50 \% \mathrm{Vmax} \approx 19$ menit

$100 \% \mathrm{Vmax} \approx 36$ menit 40 detik

$150 \% \mathrm{Vmax} \approx 77$ menit 50 detik

Gambar 6. Penurunan intensitas ikatan kompleks kanji iodin

Gambar 6 menunjukkan adanya penurunan intensitas ikatan kompleks kanji iodin. Umumnya enzim $\alpha$-Amilase memotong ikatan bagian tengah rantai sehingga dapat menurunkan kemampuan kanji mengikat Iodin. $^{8}$ Hal ini menunjukkan semakin lamanya waktu reaksi maka semakin banyak kanji yang terhidrolisis. Nilai absorbansi paling rendah dan \% kanji yang paling banyak hilang ada pada variasi $150 \%$ waktu Vmaks karena sebagian besar enzim telah berpenetrasi ke dalam serat dan menghidrolisa kanji yang ada dalam serat.

\section{KESIMPULAN}

Hasil percobaan yang telah dilakukan dapat disimpulkan bahwa: Nilai $\mathrm{Km}=8,874461$ dan Vmaks $=0,53217 \mathrm{mg} /$ menit. Berdasarkan variasi 
waktu Vmaks, proses desizing yang paling baik adalah $150 \%(\approx 77$ menit 50 detik) dari waktu Vmaks.

\section{UCAPAN TERIMA KASIH}

Ucapan terima kasih diberikan kepada Ibu Krisna dari Balai Besar Pulp dan Kertas yang telah memfasilitasi penelitian sehingga terselesaikannya karya tulis ini.

\section{PUSTAKA}

1. Anam, Khairul. Kinetika Reaksi Enzimatis. Bioteknologi IPB. (2010).

2. Lehninger. Dasar-dasar Biokimia Jilid 1 . Erlangga. (2000).

3. Rahmawati, Melia, D. Studi Kinetika Reaksi Enzimatis Endo- $\beta$ - 1,4- D- Xilanase terhadap Substrat Xilan Ampas Singkong. Universitas Jember. (2016).

4. Saropah, Dyah Ayu, dkk. Kinetika Reaksi Enzimatis Ekstrak Kasar Enzim Selulase Bakteri Selulolitik Hasil Isolasi dari Bekatul. Alchemy 2 (1), 34-45 (2012).
5. Septorini, Ragil. Perbedaan Kadar Glukosa pada Onggok yang Dihidrolisis dengan Asam Klorida, Asam Sulfat, dan Asam Oksalat. Universitas Muhammadiyah Semarang. (2008).

6. Setiabudi, Lulu. Penapisan, Isolasi dan Karakterisasi a-Amilase Pendegradasi Pati Kentang dari Isolat Danau Kakaban Kalimantan Timur. Institut Teknologi Bandung. (2009).

7. Suprapto, Agus, Muhammad Ichwan. Teknologi Persiapan Penyempurnaan. STTT Bandung. (2005).

8. Susanti, Awari. Aktifitas Enzim, Amilolitik dan Produksi Alkohol dari Pati. Universitas Andalas. Padang. (2014).

9. Wahyuni. Konversi Enzimatik Pengujian Aktivitas Enzim $\alpha$-Amilase. Institut Teknologi Bandung. (2015).

10. Winarno. Enzim Pangan. Gramedia Jakarta. (1995). 